\title{
Normative controversies in the assessment of faculty in Mexican public universities
}

\author{
Sánchez-Escobedo ${ }^{a}$, Pedro Antonio and Canto-Herrera, Pedro ${ }^{a}$ \\ ${ }^{a}$ Facultad de Educación, Universidad Autónoma de Yucatán, México.
}

\begin{abstract}
This paper analyzes recent changes in teacher assessment policies in higher education institutions in Mexico. Procedures for faculty assessment in a typical Mexican state University are analyzed with the purpose of generating insights helpful to construct a fair, pertinent and expedite assessment system.

We review guidelines to assess teachers, specifically those with the purpose of keeping or firing the teacher, even after tenure is achieved. These new regulations are seen as a key policy to improve quality in higher education. However, implications to faculty moral, organization climate and conflict with existing labor laws have not been fully considered.

It is argued that excessive federal and local regulations are, in fact, unable to ponder the complexities of academic life.

We conclude that instead of more complicated regulations, focus on qualitative peer assessment should be considered as means of effective faculty assessment.
\end{abstract}

Keywords: Faculty assessment, tenure. 


\section{Introduction}

Competitive universities around the world foresee faculty assessment as an effective strategy of teaching quality control and they aim basically to provide feedback to the teacher and foster best practices.

In Mexico, assessment of teaching in higher education is carried out since the early 1970s. In recent years, it has become a central policy to promote quality in educational services in every level of the educational system (Arredondo, Perez-Rivera, \& Aguirre-Lora, 2006).

A milestone regarding college teaching assessment in Mexico was established in 1991 by the National Council of evaluation (CONAEVA), when a system of recognition of productivity and academic performance was implemented in order to provide financial support to those Mexican academics that voluntarily consented to periodical peer assessment.

This grant/reward system has become a relatively effective strategy for the encouragement of faculty assessment and bonuses derived from positive evaluation constitute a significant portion of the annual income of many college teachers in the public higher education system in Mexico. In some cases, the amount is greater than the base salary itself.

In Mexican universities, the culture of evaluation is emerging; thus, there is still suspicions and ignorance about the rules, regulations and principles that should sustain the assessment procedure. The justice, relevance and usefulness of the assessment of academics is often criticized, mostly by those who do not get positive results. Furthermore, many handbooks, official publications and on line guidelines fail to be clear on how to evaluate specific teaching chores and responsibilities. Actually, the complexities of the academic profession are generally underestimated.

In the words of Rodriguez and Durand (2013), "... the academic profession operates through various functions, particularly around teaching and research, but also college teachers have a role in the dissemination of knowledge and in managerial duties; the picture becomes even more complex, when one considers the differences between diverse knowledge fields and professional domains " (p. 47).

The establishment of assessment systems in Mexican Universities has encounter suspicion and resistance of teachers who set forward various questions regarding criteria used and methodological issues.

Despite great progress in the assessment of academics in Mexican universities, this process is still imperfect and presents several problems. For example, existing descriptions to delineate academic responsibilities are still insufficient and in many cases ambiguous. Only the assessment of productivity, largely based upon publications, is a universally 
accepted criterion and it marks the pathway to access the prestigious roster of national researchers in Mexico.

To further complicate this matter, in many of the state public universities, assessment of academics is twofold. As an internal process, Mexican universities carry opposition exams for hiring, tenure, promotion and even permanence. As an external process, they undergo assessment by federal agencies such as El programa para el mejoramiento docente, the national teacher implementation program (PRODEP) and the national system of researchers (SNI). Many scholars have argued that assessment is repetitive and that the same evidence should be presented for different similar assessment programs as further analyzed in the following section.

In general, there are three major concerns regarding the evaluation of University Professors. The first, relates to cost-benefit issues. Professors are assessed various times by different authorities which review the same submitted evidence with similar criteria for the different purposes. This makes assessment complicated, repetitive and expensive.

The second concern refers to the absence of evaluation parameters that are accepted by the teachers themselves. This promotes rejection of many institutional assessment procedures and in many instances this process elicit suspicion with regard to the consequences of outcomes.

The third concern relates to the lack of adaptability and specificity of the assessment process that fail to include variations for field of study, contextual factors and regional demands.

\section{Case study}

This The discussion in this article is based on data derived from a case study carried out in a typical Mexican state University in the South east of the country.

A focus group with faculty from the college of education, all experts in educational assessment and teaching, analyzed and discussed the regulation and norms for faculty assessment, in particular the new internal regulations regarding tenured professors.

In 2012, this institution became one of the first public Mexican universities to implement a "law of permanence", that requires teachers with tenure to be assessed every three years. In spite of the fact that tenured faculty has been hired after winning an opposition exam and survived a trial period or "periodo de estabilidad" of 2 years.

This new regulation provides a one chance to tenured professors to implement recommendations, if the teachers is found not to meet institutional demands, before "the 
conducive legal purposes" (article 116, paragraph g, of the rules of the academic staff of the UADY, 2013).

\section{Results}

As a result of this, a discussion of three major themes emerged from the focus group: the differential teaching roles, current Mexican labor legislation and institutional regulations that underline this process. These topics will be further analyzed in the following sections.

\subsection{Roles of a University Professor}

Faculty responsibilities in Mexican Universities are delimited by hiring conditions and by differential activities demanded in the various fields of knowledge. For instance, teachers in the health field are expected to spend time in clinical some social sciences faculty seldom leave the campus,

In the university under study, Zapata (1999) demonstrated the existence of differential roles in professors in health sciences, requiring different assessment criteria for each: 1) classroom teacher, 2) instructor of clinical practice, 3) administrative duties 4) laboratory practices, and 5) practicum supervisor. Zapata argued that the criteria to evaluate each one of these roles should be consistent with their differential activities and responsibilities.

These roles are not mutually exclusive, and their performance depends on the type of appointment assigned by the authority, the field of knowledge, institutional demands and even seasonal events. Most scholars exercise all these roles at some point. Faculty assessment should consider the differential roles, and the degree to which they are required in each professor.

\subsection{Mexican labor legislation}

A major argument against assessing tenured professors rises when the labor Mexican federal law is reviewed in terms of conditions established in the law to fire a worker. It is unlikely that a mere academic assessment may set legal grounds for firing a tenured professor since chapter 47 of this law states that a worker can be fired only when justified cause exists, and posits the following examples: When the worker a) presents false certificates or references, b) shows lack of probity or honesty, acts of violence, feints, injuries etc., c) cause intentionally material damages during the performance of tasks, d) performs immoral acts of harassment etc. These few examples give the reader an idea of the 
sort of behaviors that the Federal law considers to be "justified cause" for the workers removal.

Note, that none of the previous examples are similar to the concept of "performance below expected standards of excellence" argued by University authorities. Thus, assessment for permanence of tenured professor may be against federal Mexican labor law.

\subsection{University Regulations}

New regulations approved 2013 established the possibility to assess tenured professors. Article 53, of the University's' normative code is translated as follows:

The permanence of the academic staff shall continue provided that it complies with the functions and duties laid down in this regulation for the classification and category that set by his/her appointment.

And, in article 116 it is stated: The permanence of the academic staff will be examined by the Committee of promotion and tenure of each academic unit every three years.

However, in the same regulation, article 54bis it is asserted that assessment of faculty performance is to detect areas of opportunity for strengthening the functions and academic improvement of teachers as fundamental purpose.

This is an oxymoron: either assessment is carried out in a formative fashion to provide feedback to the teacher, or it has legal and labor consequences in a summative fashion. Both approaches cannot co-exist in a same procedure.

\section{Conclusions}

It is clear that there is confusion regarding when assessment of faculty should be formative, for purposes of improving teaching practices or summative in order to make decisions concerning working conditions. Thus, these two processes should not be mixed since the purposes of each one of them are different and it would be unfair to use them interchangeably.

It is also clear, that regulation of faculty assessment should consider contextual, contractual and legal aspects, which have not been fully explored.

Perhaps, the major concern identified in this study is the excessive regulation from both federal, state and institutional authorities regarding faculty's performance. More basic peer-based assessment procedures that freely and qualitatively assess faculty's productivity and performance have proven in many country effective. Peers are usually from the same 
field of knowledge, they are acquainted with institutional and external conditions and they are all involved in departmental planning and the establishment of goals.

Peer assessment conveys a process of reflection, analysis, understanding, and feedback that elicit precise strategies for improvement and professional development.

Teacher assessment is essentially an academic process chartered with clear rules and predictable consequences, especially when it is at stake the permanence of the professor.

In the current state of affairs, it is necessary to continue with a reflective and inclusive consultation process with faculty and authorities alike.

Overregulation of academic activities and excessive legislation are indeed tendencies in the Mexican higher education system that complicate teacher assessment. There is a need to return to the simpler and effective process of peer review.

The academic life should be self-regulated and freedom of action is essential for innovation and quality in teaching, research and publishing.

\section{References}

Arredondo, V. M., Perez-Rivera, G., \& Aguirre-Lora, M. E. (2006). Didáctica general. Máxico DF: Limusa.

Beneitone, P., Esquetini, C., González, J., Martí, M., Siufu, G., \& Wagenaar, R. (2007). Reflexiones y perspectivas de la Educación Superior en América Latina Informe FinalProyecto Tunning-América latina 2004-2007. América Latina: Universidad de Deusto Universidad de Groningen.

Coll, C., Martín, E., Mauri, T., \& Mariana Miras, J. O. (2001). El Constructivismo en el Aula. En C. Coll, E. Martín, T. Mauri, \& J. O. Mariana Miras, El constructivismo en el aula (págs. 47-63). Barcelona: Editorial Graó.

Díaz Barriga Arceo, F., \& Hernández Rojas, G. (2002). Estrategias docentes para un aprendizaje significativo. Una interpretación constructivista (2da. ed.). México: McGraw-Hill.

García, J. (1999). Formación del profesorado. Necesidades y demandas. España: Praxis.

MEFI. (2013). Modelo Educativo para la Formación Integral. Mérida, Yucatán, México: Universidad Autónoma de Yucatán.

Ricco, G. (2000). Plan Nacional de Evaluación de la calidad de las universidades. Buenos Aires, Argentina: Consejo de Universidades de Argentina.

Rodríguez Liménez, J. R., \& Durand, J. P. (2013). Notas para la Evaluación del trabajo académico. (IISUE-UNAM, Ed.) Perfiles Educativos, 46-54.

Rodríguez, E. (2003). Nuevos retos y enfoques en la formación del profesorado universitario. Revista de Educación(331), 67-99.

Zapata, M. (1999). Evaluacion de los profesores de la facultad de medicina de la UADY. Tesis de Maestría. 